\title{
EDITORIAL
}

\section{Delayed cord clamping: are we ready to listen to the doctor from 1796 ?}

Journal of Perinatology (2016) 36, 1-2; doi:10.1038/jp.2015.148

Delayed cord clamping (DCC) is not a new idea. In most mammals after delivery, separation from the placenta happens after the cord stops pulsating. The separation delay results in continued perfusion to the newborn organism, and this is how evolution worked out the best and safest ways for the offspring to survive. Until recently, in humans, mothers gave birth to their newborns at home and most of the deliveries were attended by midwives or people with no formal training who had some experience in facilitating care of the mother-infant dyad. After delivery when pulsation ceased the umbilical cord was cut. In 1796, Dr Erasmus Darwin, a physician, and the grandfather of Charles Darwin, published in his book: 'another thing very injurious to the child is the tying and cutting of the navel string too soon, which should always be left till the child has not only repeatedly breathed but till all pulsation in the cord ceases. As otherwise the child is much weaker than it ought to be, a part of the blood being left in the placenta which ought to have been in the child... ${ }^{1,2}$ By the middle of the 20th century, with aggressive obstetrical care, and with active management of the third stage of labor to prevent maternal postpartum hemorrhaging, most of the deliveries took place in hospital settings, and the practice of immediate cord clamping (ICC) emerged. ${ }^{3}$ In the last 30 years, there has been a debate about the optimal timing of cord clamping. In 2006, the WHO (World Health Organization) was among the first to recognize the benefits of DCC and recommended the practice. ${ }^{3}$

Several studies evaluated the effects of DCC on term neonates, on preterm neonates and on mothers, and the results were summarized in systematic reviews. ${ }^{4-7}$ In term neonates, the benefits of DCC include higher hemoglobin concentrations and hematocrits in the neonatal period than in neonates with ICC. At 2-4 months of age infants managed with DCC, had higher ferritin levels, and lower incidence of iron deficiency anemia than infants managed with ICC. In preterm neonates, in addition to the hematological benefits observed in term neonates, significantly improved cardiovascular function was reported. Specifically, in preterm neonates managed with DCC, the blood pressure was higher in the first $24 \mathrm{~h}$ of life, there was a lower need for inotropes, better myocardial function, better organ perfusion, including increased urine output in the first $48 \mathrm{~h}$ of life than in preterm neonates managed with DCC. In addition, there was better cerebral oxygenation, and decreased incidence of intraventricular hemorrhage in the DCC group than in the ICC group. Adverse outcomes observed in preterm neonates managed with DCC include higher peak bilirubin values, and in both preterm and term infants, a higher rate of phototherapy treatment than in infants managed with ICC. Furthermore potential adverse events of DCC such as lower Apgar scores, higher need for active resuscitation and lower cord $\mathrm{pH}$ values than in neonates managed with ICC were not observed. There were no differences in the frequency of respiratory distress, polycythemia and need for exchange transfusion. Importantly, maternal outcomes such as severe postpartum hemorrhage, retained placenta and other obstetrical complications like the need for maternal transfusion were not different.
There is less available evidence to measure the extent of other potentially beneficial biological processes unrelated to simple expansion of red cell mass, however, it is important to consider that the umbilical cord blood provides important hematopoietic stem cells, endothelial cell precursors, mesenchymal progenitors and pluripotent lineage stem cells that may imprint potential lifelong health benefits. Premature neonates have high rates of complications due to immaturity, and specifically organ dysfunction and damage related to the combination of immaturity and possible organ hypoperfusion. Every organ system continues to mature beyond the neonatal period and enhancing stem cell numbers and function could provide major benefits in organ repair processes. $^{8-11}$

In recent years, based on the available data several professional organizations expressed opinions or gave recommendations regarding the timing of cord clamping.,12-15 All of these professional organizations support DCC in cases of preterm delivery. However, the American College of Obstetricians and Gynecologists (ACOG) did not find enough evidence for benefits from DCC in term infants, especially in settings with rich resources. $^{15}$

In this issue of the Journal, Backes et $a l^{16}$ present a very valuable piece to the puzzle. In this study they assessed the effects of DCC in patients delivering at 22-27 week. The study is valuable and unique in that $68 \%$ of the study population was $<25$ weeks gestation. This extremely premature patient population are routinely managed with immediate resuscitation. As intraventricular hemorrhage, necrotizing enterocolitis and number of blood transfusions are inversely related to gestational age this is precisely the population most likely to benefit from DCC. Backes et al. showed that even in these tiny premature neonates it is possible, and safe, to perform DCC. They found that in the first $24 \mathrm{~h}$ after delivery the blood pressure was higher in the DCC group than in the ICC group and the ICC group was three times more likely to need blood pressure support than infants managed with DCC. Though the numbers studied were small, these differences are remarkable and suggest that organ perfusion to organs extremely susceptible to injury are preserved by DCC.

What is the next step? Is this evidence generalizable to all nurseries in the developed world? If so, we need to develop guidelines when DCC should and should not be practiced. For example should DCC be practiced in umbilical cord or placental attachment disorders, or when the mother is a carrier for certain infectious diseases? We need to solve problems relating to the conflict of interest of DCC and umbilical cord blood banking. ${ }^{17} \mathrm{We}$ need to balance the practice of DCC and obtaining cord blood to run initial laboratory testing from umbilical cord blood, which is also a valuable blood conservation practice in the very low birth weight population. ${ }^{18}$ When these issues are addressed, and if all goes well, we will return to Dr Darwin's guidance regarding optimal timing of cord clamping in modern neonatal populations that did not exist in his time.

\section{CONFLICT OF INTEREST}

The authors declare no conflict of interest. 
GT Mandy

Section of Neonatology, Department of Pediatrics, Baylor College of Medicine, Houston, TX, USA E-mail: gmandy@bcm.edu

\section{REFERENCES}

1 Dunn PM. Dr Erasmus Darwin (1731-1802) of Lichfield and placental respiration. Arch Dis Child Fetal Neonatal Ed 2003; 88: F346-F348.

2 Darwin E. Zoonomia; Or The Laws Of Organic Life, 2nd edn. J. Johnson: London, 1796.

3 World Health Organization. Guideline: Delayed Umbilical Cord Clamping for Improved Maternal and Infant Health and Nutrition Outcomes. World Health Organization: Geneva, 2014.

4 Hutton EK, Hassan ES. Late vs early clamping of the umbilical cord in full-term neonates: systematic review and meta-analysis of controlled trials. JAMA 2007; 297(11): 1241-1252.

5 Mathew JL. Timing of umbilical cord clamping in term and preterm deliveries and infant and maternal outcomes: a systematic review of randomized controlled trials. Indian Pediatr 2011; 48(2): 123-129.

6 McDonald SJ, Middleton P, Dowswell T, Morris PS. Effect of timing of umbilical cord clamping of term infants on maternal and neonatal outcomes. Cochrane Database Syst Rev. 2013; 7: CD004074.

7 Rabe H, Diaz-Rossello JL, Duley L, Dowswell T. Effect of timing of umbilical cord clamping and other strategies to influence placental transfusion at preterm birth on maternal and infant outcomes. Cochrane Database Syst Rev. 2012; 8: CD003248.

8 Erices $\mathrm{A}$, Conget $\mathrm{P}$, Minguell JJ. Mesenchymal progenitor cells in human umbilical cord blood. Br J Haematol 2000; 109(1): 235-242.

9 Berger MJ, Adams SD, Tigges BM, Sprague SL, Wang XJ, Collins DP et al. Differentiation of umbilical cord blood-derived multilineage progenitor cells into respiratory epithelial cells. Cytotherapy 2006; 8: 480-487.
$10 \mathrm{Kim}$ JW, Kim SY, Park SY, Kim YM, Kim JM, Lee MH et al. Mesenchymal progenitor cells in the human umbilical cord. Ann Hematol 2004; 83: 733-738.

11 Tolosa JN, Park DH, Eve DJ, Klasko SK, Borlongan CV, Sanberg PR. Mankind's first natural stem cell transplant. J Cell Mol Med 2010; 14: 488-495.

12 Leduc D, Senikas V, Lalonde AB, Ballerman C, Biringer A, Delaney M et al. Clinical Practice Obstetrics Committee; Society of Obstetricians and Gynaecologists of Canada. Active management of the third stage of labour: prevention and treatment of postpartum hemorrhage. J Obstet Gynaecol Can 2009; 31: 980-993.

13 Perlman JM, Wyllie J, Kattwinkel J, Atkins DL, Chameides L, Goldsmith JP et al., Neonatal Resuscitation Chapter Collaborators. Part 11: neonatal resuscitation: 2010 international consensus on cardiopulmonary resuscitation and emergency cardiovascular care science with treatment recommendations. Circulation 2010; 122: S516-S538.

14 Sweet DG, Carnielli V, Greisen G, Hallman M, Ozek E, Plavka R et al., European Association of Perinatal Medicine. European consensus guidelines on the management of neonatal respiratory distress syndrome in preterm infants2013 update. Neonatology 2013; 103: 353-368.

15 Committee on Obstetric Practice, American College of Obstetricians and Gynecologists. Committee opinion no. 543: timing of umbilical cord clamping after birth. Obstet Gynecol 2012; 120: 1522-1526.

16 Backes $\mathrm{CH}$, Huang $\mathrm{H}$, lams JD, Bauer JA, Giannone PJ. Timing of umbilical cord clamping among infants born at 22 through 27 weeks' gestation. $J$ Perinatol 2015; 36: $35-40$.

17 Committee on Obstetric Practice; Committee on Genetics. ACOG committee opinion number 399, February 2008: umbilical cord blood banking. Obstet Gynecol 2008; 111: 475-477.

18 Carroll PD, Widness JA. Nonpharmacological, blood conservation techniques for preventing neonatal anemia--effective and promising strategies for reducing transfusion. Semin Perinatol 2012; 36: 232-243. 